\title{
Effect of wood ash and crushed rock soil amendments on red clover growth and dinitrogen fixation
}

\author{
A. Sigrun Dahlin ${ }^{1}$ and Maria Stenberg ${ }^{2}$ \\ ${ }^{1}$ Soil and Environment, SLU, P.O. Box 7014, SE-750 07 Uppsala, Sweden \\ ${ }^{2}$ Soil and Environment, SLU, P.O. Box 234, SE-532 23 Skara, Sweden \\ e-mail: Sigrun.Dahlin@slu.se
}

\begin{abstract}
The fertiliser effect of adding wood ash or crushed rock to a low-fertility soil, compared with an unamended control, was assessed in a pot experiment with a perennial ryegrass-red clover mixture. Dinitrogen $\left(\mathrm{N}_{2}\right)$ fixation by the clover and translocation of fixed $\mathrm{N}$ to the grass were determined using ${ }^{15} \mathrm{~N}$ natural abundance. The wood ash produced the highest accumulated clover biomass over two cuts, followed by the crushed rock. Chemical analyses suggested that the increase was due to $\mathrm{K}$ supply by the amendments. The wood ash also led to larger amounts of fixed $\mathrm{N}$ compared with the control. However, $\mathrm{N}_{2}$ fixation was not increased as much as biomass amount, leading to dilution of plant $\mathrm{N}$. There were minor or no treatment effects on mineralisation from soil $\mathrm{N}$ pools. This indicates that good-quality wood ash can be successfully used as a multi-element soil amendment to enhance clover growth on low-fertility soils.
\end{abstract}

Key words: circular economy, nitrogen translocation, recycling products, soil amendment

\section{Introduction}

The circular economy concept builds on renewable energy and reuse and upgrading of natural resources. This includes recycling of plant nutrients contained in industrial by-products and wastes, to replace or complement mineral fertilisers. Such nutrient sources should provide suitable concentrations of plant-available nutrients and minimise application of deleterious elements or compounds to soils. Large amounts of wood ash are produced in the bioenergy industry and recycling of this nutrient-rich by-product to agricultural or forest land can potentially contribute to a more circular economy. Wood ash not only contains high concentrations of nutrients (and potential pollutants), but is also a liming agent. In a review of the literature, Demeyer at al. (2001) concluded that application of wood ash may increase yields of a range of crops, often associated with increased availability of calcium (Ca), potassium (K), magnesium (Mg) and phosphorus (P). More recently, Haraldsen et al. (2011) found that combining meat bone meal with bottom wood ash increased growth of barley compared with meat bone meal alone. In contrast, wheat growth was not increased. Brod et al. (2012) also found no significant effect of wood ash application on crop growth, although there was an increase in readily available $\mathrm{K}$ and in some cases $\mathrm{P}$ in the soil. They concluded that the effects of the ash application were probably masked by nutrient delivery from the soil, but that wood ash may have positive $\mathrm{P}$ and $\mathrm{K}$ effects on crops on nutrient-poor soils.

Crushed rock is a by-product from quarries, and is sometimes sold and promoted as a soil amendment. Reported effects on crop yield range from a decrease due to dilution of plant-available nutrient concentrations in fertile soils (Ramezanian et al. 2013) to an increase (Kahnt et al. 1986, Bakken et al. 2000, Manning 2010). Positive results have been found for e.g. strongly weathered soils in the tropics and subtropics characterised by low cation exchange capacity (CEC) and thus low nutrient retention capacity (Manning 2010). These soils also are defined by low nutrient concentrations and poor weatherability, leading to low intrinsic nutrient supply to crops, and hence provide better scope for positive effects of application of crushed rock compared with many young arable soils in the northern hemisphere. However, nutrient-poor soils occur also in the northern hemisphere, e.g. as coarsetextured glacial tills and sandy sediments of predominantly felsic origin. These are generally poor in a range of nutrients and adding crushed mafic rock can potentially supply a range of macro- and micro-nutrients (Manning 2010) and thus may be a suitable amendment for this type of soil.

Because wood ash and crushed rock are practically devoid of nitrogen $(\mathrm{N})$, application of these to crops is generally combined with addition of organic or inorganic $\mathrm{N}$ sources. Legume crops, through their Rhizobium symbionts, have the ability to fix $\mathrm{N}_{2}$ from the atmosphere, thus limiting the need for $\mathrm{N}$ application. However, the amounts of $\mathrm{N}$ fixed by the symbionts may be limited if the availability of plant nutrients is low, both directly by deficiency of nutrients involved in the fixation process and also indirectly because of nutrient deficiency restricting host plant growth, and thus $\mathrm{N}$ demand from the host (e.g. Giller 2001). Wood ash and crushed rock may therefore be particularly suited as amendments in legume cropping. 
Dahlin et al. (2015) found that the clover component of a perennial ryegrass (Lolium perenne L.)-red-clover (Trifolium pratense L.)- mixture increased upon amendment with wood ash and crushed pyroxene-andesite rock. Earlier findings by Ferreiro et al. (2011) also suggest that the white clover (Trifolium repens L.) proportion in leys increases upon soil amendment with wood ash. However, although increased $\mathrm{N}_{2}$ fixation is a likely (partial) cause for the increased legume growth, the effects of amendment on $\mathrm{N}_{2}$ fixation were not examined in those studies.

This study investigated whether application of wood ash or crushed pyroxene-andesite can increase $\mathrm{N}_{2}$ fixation by red clover grown in a mixture with perennial ryegrass on an inherently acid and nutrient-poor soil, and sought to identify the causes of any effects observed. The study soil was used as a representative of soils derived from highly siliceous parent material, which are common grassland soils in northern Europe.

\section{Materials and methods}

A fully randomised pot experiment (4 replicates) testing amendment with by-products (Dahlin et al. 2015) was revisited. This was established in 2009 and sampled in the following growing season. A mixture of red clover (Trifolium pratense L., cv. Nancy) and perennial ryegrass (Lolium perenne L., cv. Helmer) was used as a proxy for the mixed grass-clover leys in common use. Samples from treatments with bottom ash, derived from combustion of forest fuel of mixed deciduous wood, or a commercially available crushed pyroxene-andesite rock and a nonamended control were selected in the present study for estimation of effects on $\mathrm{N}_{2}$ fixation.

Topsoil was taken from a site (Hollsby, $59^{\circ} 48^{\prime} \mathrm{N}, 13^{\circ} 31^{\prime} \mathrm{E}$ ) with postglacial silt loam (4\% clay, $69 \%$ silt, $27 \%$ sand, $2.2 \%$ organic $\mathrm{C}, \mathrm{pH}_{\mathrm{CaCl} 2} 4.8$, base saturation $40 \%$ ) originating from mainly granitic and sandstone bedrock and hosting semi-natural grassland vegetation used for grazing. Its mineralogy is dominated by quartz (53\%), plagioclase (19\%) and K-feldspar (17\%), with smaller contributions of amphibole (2\%), dioctahedral (4\%) and trioctahedral (3\%) phyllosilicates and iron oxides (1\%). The cation exchange capacity of the sampled topsoil was 9 cmolc $\mathrm{kg}^{-1}$ and concentrations of most nutrients were low (Table 1). The soil was sieved through $8 \times 18 \mathrm{~mm}$ mesh and homogenised before use.

Portions of $6 \mathrm{~kg}$ dry weight (DW) were weighed into pots (220 mm inner $\varnothing, 250 \mathrm{~mm}$ depth) and the amendment was added. Wood ash was applied at a rate corresponding to $0.14 \mathrm{~kg} \mathrm{~m}^{-2}$, conforming with the maximum allowable 7-year application rate for trace elements set by the Swedish Environmental Protection Agency (1994). The ash application rate was limited by the nickel ( $\mathrm{Ni}$ ) concentration (Table 2). However, the application rate for the crushed rock surpassed these limits, on the assumption that element availability was low, with application following the supplier's recommendation $\left(5.0 \mathrm{~kg} \mathrm{~m}^{-2}\right)$.

Table 1. Original total and extractable (AL ${ }^{\mathrm{a}}$ or EDTA) concentrations of nutrients in the soil used for the pot experiment

\begin{tabular}{|c|c|c|c|c|c|}
\hline Nutrient & $\begin{array}{l}\text { Total } \\
\mathrm{g} \mathrm{kg}^{-1}\end{array}$ & $\begin{array}{c}\mathrm{AL} \\
\mathrm{mg} \mathrm{kg}^{-1}\end{array}$ & Nutrient & $\begin{array}{l}\text { Total } \\
\mathrm{mg} \mathrm{kg}^{-1}\end{array}$ & $\begin{array}{c}\text { EDTA } \\
\mathrm{mg} \mathrm{kg}^{-1}\end{array}$ \\
\hline$N$ & 1.9 & na & Co & 2.6 & 0.07 \\
\hline$P$ & 0.78 & 13 & $\mathrm{Cu}$ & 6.9 & 2.3 \\
\hline K & 25 & 23 & $\mathrm{Mn}$ & 531 & 35 \\
\hline $\mathrm{Ca}$ & 10 & 490 & Mo & 0.40 & b.r. ${ }^{b}$ \\
\hline $\mathrm{Mg}$ & 3.0 & 12 & $\mathrm{Zn}$ & 46 & 4.6 \\
\hline$S$ & 0.33 & n.a. & & & \\
\hline
\end{tabular}

Once amendments had been added, all soil samples (including the unamended controls) were homogenised and the mixture of red clover and perennial ryegrass was sown on 27 July 2009. The seedlings were thinned to 10 plants of each species per pot around 2 weeks after emergence. Pots were also sown with pure ryegrass to serve as reference plants for estimation of $\mathrm{N}_{2}$ fixation. The pots were kept in a fenced outdoor area and irrigated with deionised water to complement precipitation during the growing season, while occasional drainage was collected in saucers underneath the pots and recycled to the pot as part of the next irrigation. Pots were over-wintered at $0{ }^{\circ} \mathrm{C}$ and returned to the outdoor area in April. They were harvested in two cuts, on 15 June and 20 July, when the clover was at budding to early flowering stage (BBCH 50-60) and the grass was at earing stage (BBCH 51-59). Plants were cut at $5 \mathrm{~cm}$ above the soil surface to avoid contamination with soil. Shoot material was force-dried 
A.S. Dahlin \& M. Stenberg (2017) 26: 188-197

at $50{ }^{\circ} \mathrm{C}$ in perforated plastic bags, weighed, milled in a Grindomix GM 200 cutting mill with a titanium knife and dry matter content was determined on subsamples after drying at $105^{\circ} \mathrm{C}$. Care was taken at all stages to prevent sample contamination (Dahlin et al. 2012).

Table 2. Characteristics of the crushed rock (CR) and wood ash (WA), and product and nutrient application rates used in the experiment. The particle size distribution of the crushed rock was <2 $\mu \mathrm{m} 2 \%$; 2-6 $\mu \mathrm{m} \mathrm{2 \% ;} \mathrm{6-20} \mu \mathrm{m} 5 \%$; $20-$

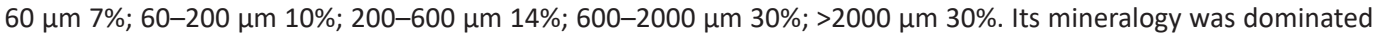
by plagioclase (60\%), followed by clay minerals (sum 15\%), K-feldspar (7.5\%), quartz (6.7\%) and pyroxene (6.6\%) (Ramezanian et al. 2013).

\begin{tabular}{|c|c|c|c|c|c|c|}
\hline & \multicolumn{3}{|c|}{ Amendment characteristics } & \multicolumn{3}{|c|}{ Application rates } \\
\hline & Unit & $\mathrm{CR}$ & WA & Unit & $\mathrm{CR}$ & WA \\
\hline Amount of product & & na & na & $\mathrm{kg} \mathrm{m}^{-2}$ & 5.0 & 0.14 \\
\hline Liming effect & $\% \mathrm{CaO}$ & 1.9 & 51.3 & & na & na \\
\hline $\mathrm{C}$ & $\%$ & 0.005 & 1.1 & $\mathrm{~g} \mathrm{~m}^{-2}$ & - & 1.5 \\
\hline $\mathrm{N}$ & $\mathrm{g} \mathrm{kg}^{-1}$ & 1.0 & 0.1 & $\mathrm{~g} \mathrm{~m}^{-2}$ & - & 0.008 \\
\hline$P$ & $\mathrm{~g} \mathrm{~kg}^{-1}$ & 1.2 & 21 & $\mathrm{~g} \mathrm{~m}^{-2}$ & 6.0 & 3.1 \\
\hline K & $\mathrm{g} \mathrm{kg}^{-1}$ & 2.6 & 69 & $\mathrm{~g} \mathrm{~m}^{-2}$ & 12.8 & 10.0 \\
\hline $\mathrm{Ca}$ & $\mathrm{g} \mathrm{kg}^{-1}$ & 13 & 324 & $\mathrm{~g} \mathrm{~m}^{-2}$ & 65.8 & 46.9 \\
\hline Mg & $\mathrm{g} \mathrm{kg}^{-1}$ & 17 & 40 & $\mathrm{~g} \mathrm{~m}^{-2}$ & 84.1 & 5.79 \\
\hline$S$ & $\mathrm{~g} \mathrm{~kg}^{-1}$ & 0.09 & 0.82 & $\mathrm{~g} \mathrm{~m}^{-2}$ & 0.46 & 0.12 \\
\hline $\mathrm{Cd}$ & $\mathrm{mg} \mathrm{kg}^{-1}$ & 0.04 & 0.27 & $\mathrm{mg} \mathrm{m}^{-2}$ & 0.19 & 0.04 \\
\hline Co & $\mathrm{mg} \mathrm{kg}^{-1}$ & 12 & 21 & $\mathrm{mg} \mathrm{m}^{-2}$ & 59 & 3.0 \\
\hline $\mathrm{Cu}$ & $\mathrm{mg} \mathrm{kg}^{-1}$ & 7.3 & 118 & $\mathrm{mg} \mathrm{m}^{-2}$ & 36 & 17 \\
\hline $\mathrm{Hg}$ & $\mathrm{mg} \mathrm{kg}^{-1}$ & b.r. ${ }^{a}$ & b.r. ${ }^{a}$ & $\mathrm{mg} \mathrm{m}^{-2}$ & $-^{\mathrm{b}}$ & $--^{b}$ \\
\hline $\mathrm{Mn}$ & $\mathrm{mg} \mathrm{kg}^{-1}$ & 375 & 7810 & $\mathrm{mg} \mathrm{m}^{-2}$ & 1850 & 1130 \\
\hline Mo & $\mathrm{mg} \mathrm{kg}^{-1}$ & 0.20 & $<6$ & $\mathrm{mg} \mathrm{m}^{-2}$ & 1.0 & 0.4 \\
\hline $\mathrm{Ni}$ & $\mathrm{mg} \mathrm{kg}^{-1}$ & 9.7 & 121 & $\mathrm{mg} \mathrm{m}^{-2}$ & 48.2 & 17.5 \\
\hline $\mathrm{Zn}$ & $\mathrm{mg} \mathrm{kg}^{-1}$ & 46 & 182 & $\mathrm{mg} \mathrm{m}^{-2}$ & 228 & 26 \\
\hline
\end{tabular}

Below the reported limit ( 0.02 and $0.01 \mathrm{mg} \mathrm{kg}^{-1}$ for crushed rock and wood ash, respectively); ${ }^{\mathrm{b}}$ Could not be calculated

Soil samples, wood ash and crushed rock were: (a) digested in concentrated $\mathrm{HNO}_{3}, \mathrm{HCl}$ and $\mathrm{HF}$, and cadmium (Cd), cobalt (Co), copper (Cu), mercury ( $\mathrm{Hg})$, molybdenum (Mo), nickel (Ni), sulphur (S) and zinc (Zn) were measured using ICP-SFMS. They were also (b) fused with lithium metaborate and dissolved in $\mathrm{HNO}_{3}$, and aluminium (Al), $\mathrm{Ca}, \mathrm{K}, \mathrm{Mg}$, manganese $(\mathrm{Mn})$ and $\mathrm{P}$ were measured by ICP-AES. The plant material was digested in concentrated ultrapure $\mathrm{HNO}_{3}$ and $\mathrm{HF}$, followed by filtering, and all elements were measured using ICP-SFMS. Soil electrical conductivity (EC; used as an indicator of general nutrient level of the soil) was measured in a solution of deionised water and then $\mathrm{CaCl}_{2}$ was added (0.01M) and $\mathrm{pH}$ determined (Sumner 1994). EDTA-extractable P, K, Ca, Mg, S, Co, $\mathrm{Cu}, \mathrm{Mn}, \mathrm{Mo}$ and $\mathrm{Zn}$ were analysed after extraction according to Streck and Richter (1997), with the modification that Na-EDTA was used, and the extracts were analysed by ICP-MS ELAN 6100 DRC (Perkin Elmer SCIEX, Waltham, MA, USA). Total $\mathrm{N}$ and carbon (C) concentrations in plant and soil samples were analysed by high-temperature induction furnace combustion using a LECO CN2000 analyser (LECO Corporation, St Joseph, MI, USA) and ${ }^{15} \mathrm{~N}$ abundance of plant samples was determined at UC Davis Stable Isotope Facility (California, USA).

For site characterisation, soil was also extracted with ammonium lactate/acetic acid (AL) solution and analysed for P, K, Ca and Mg (SSI 1993). Cation exchange capacity (CEC) and base saturation (BS) were determined according to Parker (1929) and Thomas (1982). Soil particle size distribution was determined according to ISO 11277:1998 (ISO 1998). The mineralogical composition of <2 $\mathrm{mm}$ soil was determined by XRD on spray-dried random powder samples (Hillier 1999), with analysis performed using a full pattern fitting method (Omotoso et al. 2006).

Certified reference material (NIST Wheat Flour, National Institute of Standards and Technology, Gaitersburg, MD, USA) was included in all batches for plant material analysis and Al concentration in the plant matter was taken as an indicator of soil contamination. For soil analyses, an in-house standard was included in each batch. 
Dinitrogen fixation was estimated by the ${ }^{15} \mathrm{~N}$ natural abundance method (Shearer and Kohl 1986):

$$
\% \text { Ndfa }=\left(\delta^{15} \mathrm{~N}_{\text {reference crop }}-\delta^{15} \mathrm{~N}_{\text {legume }}\right) \div\left(\delta^{15} \mathrm{~N}_{\text {reference crop }}-\mathrm{B}\right) \times 100
$$

where \%Ndfa is the percentage $\mathrm{N}$ derived from air (i.e. fixed by the symbiont), $\delta^{15} \mathrm{~N}$ is the natural abundance of ${ }^{15} \mathrm{~N}$ in the reference crop or legume, and $\mathrm{B}$ is the natural abundance of ${ }^{15} \mathrm{~N}$ in shoots of legumes that are fully dependent upon $\mathrm{N}_{2}$ fixation. Grass in pure stands was used as the reference crop and the lowest determined $\delta^{15} \mathrm{~N}$ value was used as the $B$ value (Hansen and Vinther 2001).

Translocation of clover $\mathrm{N}$ to the grass was estimated according to Snoeck et al. (2000) using ryegrass in pure stand as the reference crop:

$$
\% \mathrm{~N}_{\text {translocated }}=\left(\delta^{15} \mathrm{~N}_{\text {grass in pure stand }}-\delta^{15} \mathrm{~N}_{\text {grass in mixed stand }}\right) \div\left(\delta^{15} \mathrm{~N}_{\text {grass in pure stand }}-\mathrm{B}\right) \times 100
$$

Amount of fixed $\mathrm{N}$ translocated to the grass was estimated from the amount of translocated clover $\mathrm{N}$ and the percentage of $\mathrm{N}$ derived from air (\%Ndfa) in clover of the same cut.

Data were analysed by variance analysis using JMP Pro 11.2.0 (SAS Institute Inc., Cary, NC, USA). If needed, data were transformed to the natural logarithm or square root to achieve normal distribution of residuals. When significant differences $(p \leq 0.05)$ were observed, means were compared by Student's t-test. Multiple linear regressions followed by pairwise correlations were performed using the Holm (1979) method to control the family-wise error of the multiple regressions; plant biomass accumulation was tested versus soil pH and EC and plant concentrations of all measured elements (plant nutrients and $\mathrm{Cd}$ ); amount of fixed $\mathrm{N}$ was tested versus the same variable and also plant biomass DW. All differences described in the text are significant at $p \leq 0.05$.

\section{Results}

\section{Soil characteristics}

Soil $\mathrm{pH}$ and EC were significantly higher in the wood ash treatment than in the control (Table 3). The EDTAextractable concentrations of $\mathrm{K}, \mathrm{Ca}$ and $\mathrm{Mg}$ in the soil were increased by addition of wood ash and the Mg concentration by addition of crushed rock. Extractable concentrations of other elements were not significantly affected by the amendments, however.

Table 3. Soil pH in $0.01 \mathrm{M} \mathrm{CaCl}_{2}$, electrical conductivity (EC) and EDTA-extractable element concentrations 14 months after amendment

\begin{tabular}{|c|c|c|c|c|c|}
\hline & Unit & Control & Crushed rock & Wood ash & $p$ value \\
\hline $\mathrm{pH}$ & & $5.0 \pm 0.0^{b}$ & $5.0 \pm 0.0^{b}$ & $5.3 \pm 0.0^{a}$ & 0.0002 \\
\hline EC & $\mu S \mathrm{~cm}^{-1}$ & $93 \pm 6^{b}$ & $104 \pm 4^{a b}$ & $118 \pm 3^{a}$ & 0.0084 \\
\hline$P$ & $\mathrm{~g} \mathrm{~kg}^{-1}$ & $0.026 \pm 0.001$ & $0.027 \pm 0.002$ & $0.027 \pm 0.001$ & ns \\
\hline K & $\mathrm{g} \mathrm{kg}^{-1}$ & $0.020 \pm 0.001^{b}$ & $0.021 \pm 0.001^{b}$ & $0.034 \pm 0.002^{a}$ & $<0.0001$ \\
\hline $\mathrm{Ca}$ & $\mathrm{g} \mathrm{kg}^{-1}$ & $0.99 \pm 0.03^{b}$ & $1.00 \pm 0.01^{b}$ & $1.21 \pm 0.02^{a}$ & 0.0001 \\
\hline $\mathrm{Mg}$ & $\mathrm{g} \mathrm{kg}^{-1}$ & $0.016 \pm 0.001^{c}$ & $0.022 \pm 0.003^{b}$ & $0.029 \pm 0.001^{a}$ & $<0.0001$ \\
\hline $\mathrm{Cd}$ & $\mathrm{mg} \mathrm{kg}^{-1}$ & $0.093 \pm 0.003$ & $0.091 \pm 0.002$ & $0.093 \pm 0.001$ & ns \\
\hline Co & $\mathrm{mg} \mathrm{kg}^{-1}$ & $0.15 \pm 0.01$ & $0.13 \pm 0.01$ & $0.11 \pm 0.01$ & ns \\
\hline $\mathrm{Cu}$ & $\mathrm{mg} \mathrm{kg}^{-1}$ & $1.4 \pm 0.1$ & $1.4 \pm 0.1$ & $1.6 \pm 0.1$ & ns \\
\hline $\mathrm{Mn}$ & $\mathrm{mg} \mathrm{kg}^{-1}$ & $26 \pm 1$ & $21 \pm 2$ & $22 \pm 2$ & ns \\
\hline Mo & $\mathrm{mg} \mathrm{kg}^{-1}$ & $0.025 \pm 0.007$ & $0.021 \pm 0.003$ & $0.019 \pm 0.002$ & ns \\
\hline $\mathrm{Ni}$ & $\mathrm{mg} \mathrm{kg}^{-1}$ & $0.89 \pm 0.07$ & $1.1 \pm 0.13$ & $1.0 \pm 0.16$ & ns \\
\hline $\mathrm{Zn}$ & $\mathrm{mg} \mathrm{kg}^{-1}$ & $3.6 \pm 0.2$ & $3.4 \pm 0.1$ & $4.0 \pm 0.5$ & ns \\
\hline
\end{tabular}
with crushed rock or wood ash and in the non-amended control. Data is given as Least-Squares Means \pm SEM. 


\section{Plant growth}

Addition of both ash and crushed rock increased clover biomass over the growing season (Fig. 1), as a result of more rapid plant establishment and initial growth compared with the unamended control. Clover dry weight at the first cut was significantly highest on the ash-amended soil (Fig. 1). All treatments differed significantly at the second cut (Fig. 1) and summed across the two cuts (not shown); the highest clover dry weight was found on the ash-amended soil, followed by the crushed rock-amended soil. The ryegrass, on the other hand, established quickly in all treatments, but its biomass decreased strongly from the first to the second cut (Fig. 1). Ash- and crushed rock-amended ryegrass accumulated more biomass than the control in the first cut, but there were no significant differences in the second cut or for both cuts added together (not shown).

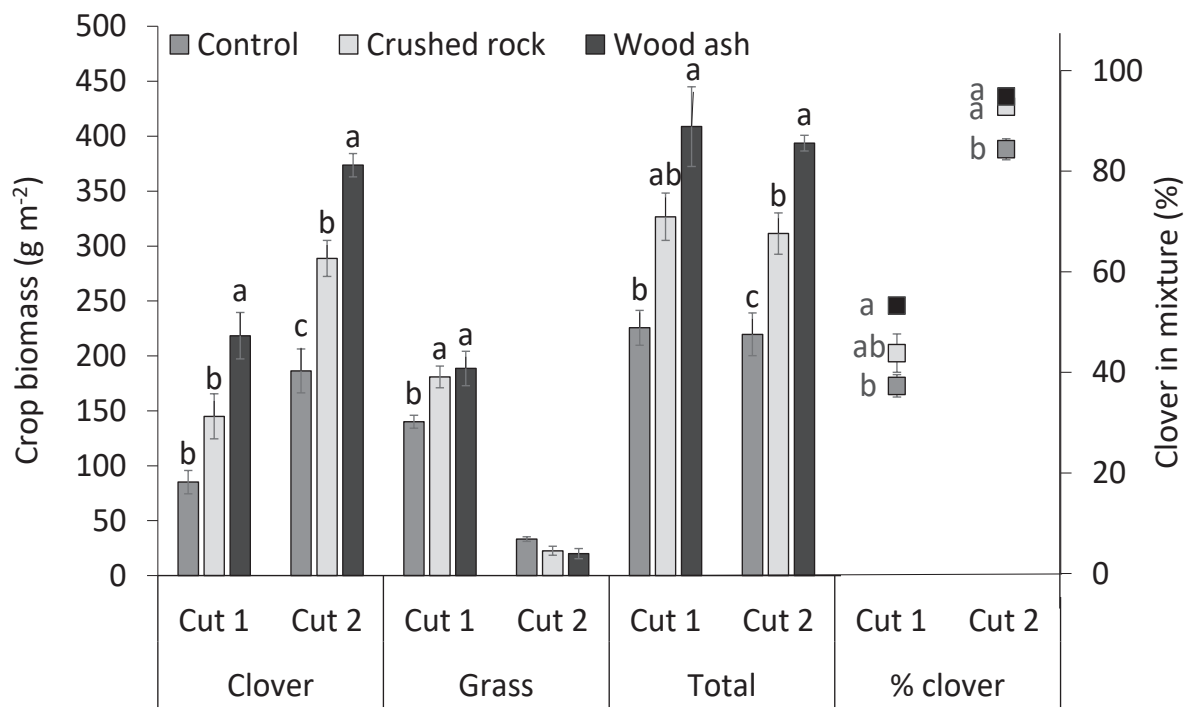

Fig. 1. Red clover, perennial ryegrass and total biomass (primary y axis), and percentage of clover in the mixture (secondary y axis). Data are given as Least-Squares Means, error bars indicate SEM, and different letters (a$c)$ indicate significant differences between treatments for crop species, crop mixture or clover percentage at each cut $(p \leq 0.05 ; \mathrm{n}=4)$.

The proportion of clover in the crop mixture increased from an average of $45 \%$ in the first cut to $90 \%$ in the second cut (Fig. 1). The clover proportion was consistently higher on the ash-amended soil, and also on the crushed rock-amended soil in the second cut, than in the control.

\section{Plant $\mathrm{N}$ concentrations and $\mathrm{N}$ fixation}

The total $\mathrm{N}$ concentration in the clover was higher in the control treatment than in the crushed rock and ash treatments (Fig. 2). Due to its larger biomass, the ash-amended clover nevertheless accumulated more total $\mathrm{N}$ than the control at the first cut, while the crushed rock-amended clover was not significantly different from the other treatments (Fig. 3). The grass accumulated considerably less total $\mathrm{N}$ than the clover (Fig. 3). The grass in the control accumulated more total $\mathrm{N}$ than the grass on the amended soils in the second cut $\left(0.51 \mathrm{~g} \mathrm{~m}^{-2}\right.$ compared with $0.23 \mathrm{~g}$ $\mathrm{m}^{-2}$ in the control and amended soils; $p=0.0003$ ), an effect associated with its higher total $\mathrm{N}$ concentration (Fig. 2).

The percentage of clover $\mathrm{N}$ derived from air (i.e. by $\mathrm{N}_{2}$ fixation) averaged $75 \%$ at the first cut and increased to around $83 \%$ at the second cut, with no significant differences between treatments (data not shown). The amount of $\mathrm{N}$ derived from air by clover in the first cut was thus significantly higher in the ash-amended clover than in the control, while the crushed rock-amended clover was not significantly different from the other treatments (Fig. 3 ). The second cut showed the same trend, but differences were non-significant. Nitrogen derived from air by the clover and translocated to the grass contributed on average 2, 16 and $17 \%$ of $\mathrm{N}$ in grass on the unamended control, ash-amended and crushed rock-amended soil, respectively, with no significant differences between cuts (data not shown). Summed across the two cuts, the amount of fixed $\mathrm{N}$ present in clover and grass was higher on the ash-amended soil than in the control, whereas that on the crushed rock-amended soil was not significantly different from the other treatments (Fig. 3). 


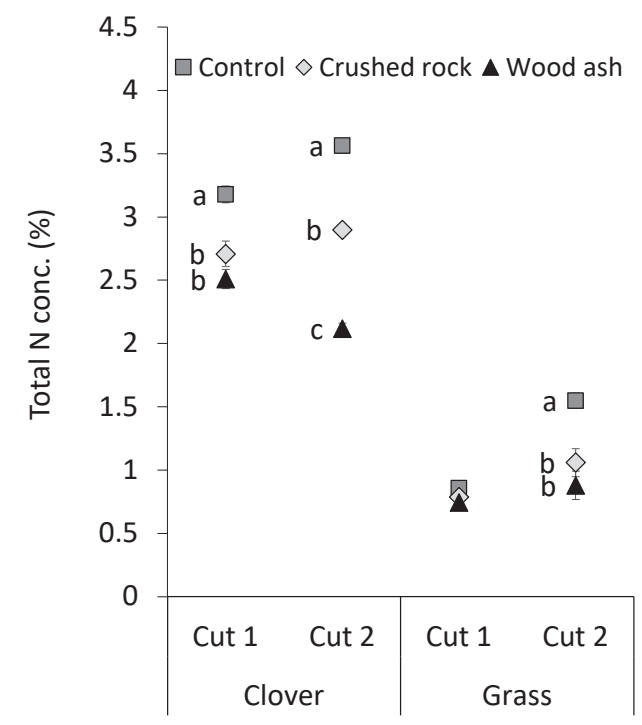

Fig. 2. Total $\mathrm{N}$ concentration in red clover and perennial ryegrass. Data are given as Least-Squares Means, error bars indicate SEM, and different letters (a-c) indicate significant differences between treatments for each crop species at each cut $(p \leq 0.05 ; n=4)$.

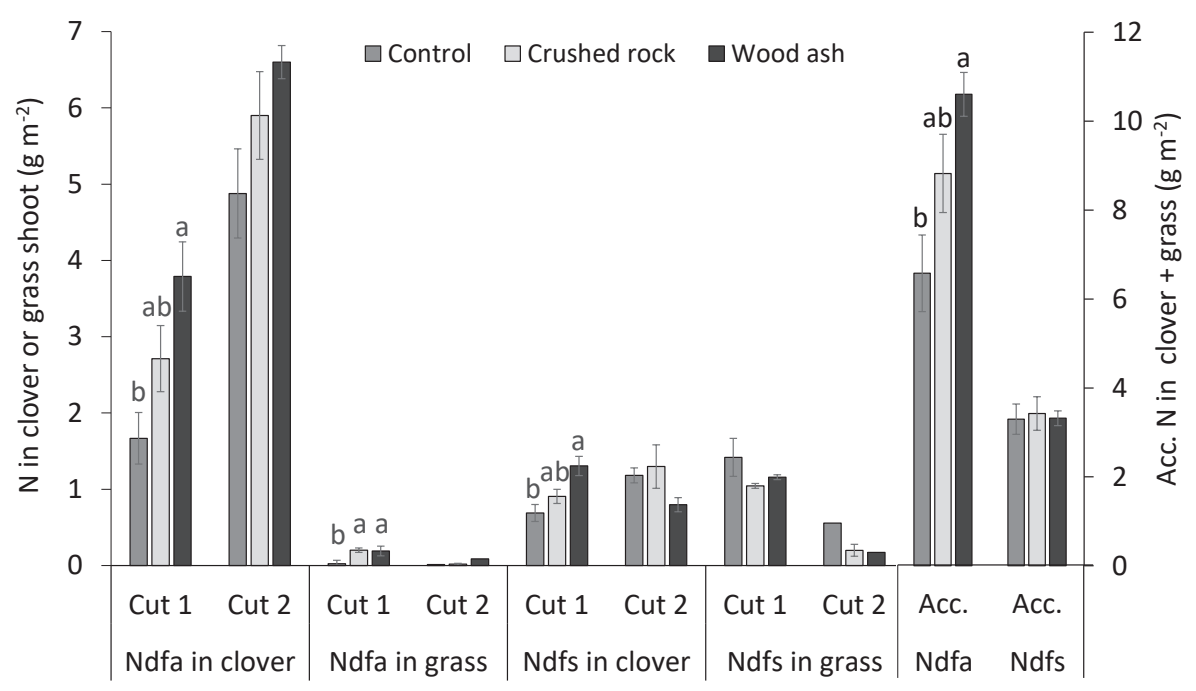

Fig. 3. Amounts of $\mathrm{N}$ derived from air ( $\mathrm{Ndfa}$ ) and soil ( $\mathrm{Ndfs}$ ) in red clover and perennial ryegrass shoots at cuts 1 and 2 (primary y axis) and total amount accumulated in clover + grass across the two cuts (secondary y axis). Data are given as Least-Squares Means, error bars indicate SEM and letters $(a, b)$ indicate significant differences between treatment for each species at each cut, and between treatments for the accumulated amounts ( $p \leq 0.05 ; n=4)$.

The amount of soil $\mathrm{N}$ used by the clover during the first growth was significantly higher in the ash-amended plants than in the control, while the crushed rock-amended clover was not significantly different from the other treatments (Fig. 3). There were no significant differences between treatments in the second cut, or in the total amounts across the two cuts.

\section{Plant element concentrations and offtakes}

Application of wood ash significantly increased clover $\mathrm{K}$ concentration and decreased the concentrations of $\mathrm{P}, \mathrm{Ca}$, $\mathrm{Mg}, \mathrm{Cd}, \mathrm{Co}, \mathrm{Cu}, \mathrm{Mn}, \mathrm{Ni}$ and $\mathrm{Zn}$ in one or both cuts compared with the control, but did not significantly affect Mo concentration (Table 1). Application of crushed rock also increased clover $\mathrm{K}$ concentration and decreased the concentrations of most other elements, but to a lower degree. However, clover Mo concentration was significantly reduced by the crushed rock at the second cut in contrast to the wood ash. 
Grass $\mathrm{K}$ concentration was increased by the wood ash in the first cut, and $\mathrm{P}, \mathrm{Ca}, \mathrm{Cd}, \mathrm{Co}, \mathrm{Cu}, \mathrm{Mn}, \mathrm{Ni}$ and $\mathrm{Zn}$ concentrations were decreased compared with the control in one or both cuts (Table 2). In addition, the grass Mo concentration increased in the first cut, but decreased in the second. Crushed rock did not significantly affect the grass $\mathrm{K}$ concentration, but decreased concentrations of most other elements, albeit often to a smaller extent than the wood ash.

Combined $\mathrm{K}$ offtake by both plant species in the two cuts was significantly highest in the wood ash treatment, intermediate in the crushed rock treatment and lowest in the control (Table 4). Calcium, Mg and Mo offtakes were also higher in the wood ash treatment, and Mg offtake was higher in the crushed rock treatment, compared with the control.

Table 4. Element offtake by harvested shoots of red clover and perennial ryegrass, combined for the two cuts after amendment. Data is given as Least-Squares Means \pm SEM.

\begin{tabular}{|c|c|c|c|c|c|}
\hline Element & Unit & Control & Crushed rock & Wood ash & $p$ value \\
\hline$P$ & $\mathrm{~g} \mathrm{~m}^{-2}$ & $1.16 \pm 0.10$ & $1.21 \pm 0.06$ & $1.25 \pm 0.05$ & ns \\
\hline K & $\mathrm{g} \mathrm{m}^{-2}$ & $2.95 \pm 0.25^{c}$ & $4.56 \pm 0.18^{b}$ & $8.02 \pm 0.35^{a}$ & $<0.0001$ \\
\hline $\mathrm{Ca}$ & $\mathrm{g} \mathrm{m}^{-2}$ & $12.5 \pm 1.2^{b}$ & $16.3 \pm 1.3^{b}$ & $21.1 \pm 1.6^{\mathrm{a}}$ & 0.006 \\
\hline $\mathrm{Mg}$ & $\mathrm{g} \mathrm{m}^{-2}$ & $2.66 \pm 0.18^{b}$ & $3.67 \pm 0.25^{\mathrm{a}}$ & $4.20 \pm 0.20^{\mathrm{a}}$ & 0.0018 \\
\hline $\mathrm{Cd}$ & $\mathrm{mg} \mathrm{m}^{-2}$ & $0.010 \pm 0.001$ & $0.009 \pm 0.001$ & $0.006 \pm 0.001$ & ns \\
\hline Co & $\mathrm{mg} \mathrm{m}^{-2}$ & $0.031 \pm 0.002$ & $0.040 \pm 0.005$ & $0.039 \pm 0.003$ & ns \\
\hline $\mathrm{Cu}$ & $\mathrm{mg} \mathrm{m}^{-2}$ & $5.0 \pm 0.5$ & $5.5 \pm 0.3$ & $4.9 \pm 0.2$ & ns \\
\hline $\mathrm{Mn}$ & $\mathrm{mg} \mathrm{m}^{-2}$ & $72 \pm 5$ & $81 \pm 6$ & $64 \pm 5$ & ns \\
\hline Mo & $\mathrm{mg} \mathrm{m}^{-2}$ & $1.7 \pm 0.1 b$ & $1.5 \pm 0.1 \mathrm{~b}$ & $3.2 \pm 0.1^{\mathrm{a}}$ & $<0.0001$ \\
\hline $\mathrm{Ni}$ & $\mathrm{mg} \mathrm{m}^{-2}$ & $0.50 \pm 0.04$ & $0.62 \pm 0.06$ & $0.69 \pm 0.07$ & ns \\
\hline $\mathrm{Zn}$ & $\mathrm{mg} \mathrm{m}^{-2}$ & $23 \pm 2$ & $29 \pm 2$ & $31 \pm 4$ & ns \\
\hline
\end{tabular}

\section{Relations of plant DW and $\mathrm{N}_{2}$ fixation with soil and plant variables}

Clover biomass was strongly and positively correlated with its $\mathrm{K}$ concentration in both cuts (Table 5). Clover concentrations of most other nutrients (and $\mathrm{Cd}$ ) were inversely correlated with clover biomass in the second cut, but only N, Cu and Mn showed significant correlations in the first cut. Grass biomass was generally not significantly correlated with its nutrient concentrations, except for an inverse correlation with $\mathrm{P}$ concentration in the first cut.

Table 5. Correlations between biomass dry weight (DW) and amounts of fixed $\mathrm{N}$ and soil pH, electrical conductivity (EC) and plant element concentrations at cut 1 and 2 for red clover and perennial ryegrass after controlling for family-wise error rate (Holm 1979), given as correlation coefficient $/ p$-value

\begin{tabular}{|c|c|c|c|c|c|c|}
\hline \multirow[b]{2}{*}{ Factor } & \multicolumn{2}{|l|}{ Red clover DW } & \multicolumn{2}{|c|}{ Perennial ryegrass DW } & \multicolumn{2}{|c|}{ Amount of fixed $\mathrm{N}$} \\
\hline & Cut 1 & Cut 2 & Cut 1 & Cut 2 & Cut 1 & Cut 2 \\
\hline Clover DW & - & - & - & - & $0.974 /<0.0001$ & $0.519 / 0.0006$ \\
\hline $\mathrm{N}$ & $-0.754 / 0.0046^{a}$ & $-0.943 /<0.0001^{a}$ & ns & ns & $0.988 /<0.0001^{a}$ & $0.936 /<0.0001^{\circ}$ \\
\hline$P$ & ns & $-0.867 / 0.0003$ & $-0.819 / 0.0011$ & ns & ns & ns \\
\hline K & $0.787 / 0.0024$ & $0.844 / 0.0006$ & ns & ns & ns & ns \\
\hline $\mathrm{Ca}$ & ns & $-0.863 / 0.0003$ & ns & ns & ns & ns \\
\hline $\mathrm{Mg}$ & ns & $-0.726 / 0.0075$ & ns & ns & ns & ns \\
\hline $\mathrm{Cd}$ & ns & $-0.749 / 0.0051$ & ns & ns & ns & ns \\
\hline Co & ns & ns & ns & ns & ns & ns \\
\hline $\mathrm{Cu}$ & $-0.787 / 0.0024$ & $-0.919 /<0.0001$ & ns & ns & ns & ns \\
\hline $\mathrm{Mn}$ & $-0.746 / 0.0053$ & ns & ns & ns & ns & ns \\
\hline Mo & ns & ns & ns & ns & ns & ns \\
\hline $\mathrm{Ni}$ & ns & ns & ns & ns & ns & ns \\
\hline Zn & ns & $-0.735 / 0.0065$ & ns & ns & ns & ns \\
\hline $\mathrm{pH}$ & ns & $0.336 / 0.0039$ & ns & ns & ns & ns \\
\hline EC & $0.630 / 0.0001$ & $0.599 / 0.0002$ & ns & ns & $0.653 /<0.0001$ & $0.785 / 0.0025$ \\
\hline
\end{tabular}

${ }^{\mathrm{a}} \mathrm{N}$ in the regression was clover total $\mathrm{N}$ 
The amount of $\mathrm{N}$ fixed by the clover was significantly positively correlated with soil EC and with clover DW and total N (Table 5). However, there were no significant correlations with soil pH or individual nutrient (or Cd) concentrations in the clover after control of family-wise error.

\section{Discussion}

The clover and grass in the mixture grown had relatively similar biomass at the first cut, but the grass proportion fell sharply in the second cut, reflecting the experimental conditions where no fertiliser $\mathrm{N}$ was added, as well as the low content of organic matter and low N-supplying capacity of the soil. The higher clover biomass on the ash-amended soils than in the control indicates that wood ash may help boosting clover growth on low-fertility soils, corroborating findings by Ferreiro et al. (2011), and may help to increase the clover proportion where the clover content is too low for optimum feed quality. The increased yield of common bean (Phaseolus vulgaris L.) on an acid tropical soil after wood ash application was attributed to both the liming effect and the application of relatively balanced proportions of $\mathrm{Ca}, \mathrm{Mg}$ and $\mathrm{K}$ (Zake and Nkwiine 1982). In the present study, the effect was probably mainly through provision of $\mathrm{K}$, indicated through a positive correlation between plant $\mathrm{K}$ concentration and dry matter accumulation in both cuts (Table 6). Meanwhile, concentrations of $\mathrm{Ca}$ and $\mathrm{Mg}$ (and several other nutrients) were apparently diluted by the increased biomass accumulation, as reported previously (Jarrell and Beverly 1982), corroborating that in the control treatment these plant concentrations were present at a margin above the minimum needs of the plants, as suggested by e.g. Pilbeam and Morley (2007) and Whitehead (2000). The increased offtake of $\mathrm{K}, \mathrm{Ca}, \mathrm{Mg}$ and Mo nevertheless suggests supply of these nutrients from the wood ash. This was corroborated by the increased EDTA-extractable concentrations of $\mathrm{K}, \mathrm{Ca}$ and $\mathrm{Mg}$, but not of Mo. In contrast, P was not supplied significantly by the wood ash, contradicting results reported by e.g. Brod et al. (2014), who found $\mathrm{P}$ in a bottom wood ash to be approximately as available to wheat (Triticum aestivum L.) as mineral fertiliser $P$ in a sand-peat mixture of low nutrient content. Similarly, Clapham and Zibilske (1992) found a significant P supply from wood ash to spinach (Spinacia oleracea L.).

The crushed rock also increased clover biomass production at the second cut and supplied $\mathrm{K}$ and $\mathrm{Mg}$, as indicated by the higher EDTA-extractable concentrations of these elements and higher offtakes compared with the unamended control. However, the effect was smaller than that of the wood ash. An increase in clover biomass has also been found in a study on another nutrient-poor soil after application of crushed rock of the same origin (Dahlin et al. 2015), but not on more fertile soils (Campbell 2009, Ramezanian et al. 2013). Moreover, Haraldsen et al. (2011) did not find any increase in AL-extractable concentrations of $\mathrm{Ca}, \mathrm{K}, \mathrm{Mg}$ and $\mathrm{P}$, or any yield increase or increased offtake of $\mathrm{K}$ and $\mathrm{P}$ by barley or wheat, when $\mathrm{N}$-rich recycling products were combined with olivine. This suggests that a significant positive effect in northern hemisphere soils will be found mainly at high application rates to nutrient-poor, acid soils, although positive fertiliser effects have often been found on strongly weathered tropical and subtropical soils (reviewed by Manning 2010).

The $\mathrm{N}_{2}$ fixation rate observed here $\left(\sim 711 \mathrm{~g} \mathrm{~N} \mathrm{~m}^{-2}\right)$ was of the same order of magnitude as the $\sim 7-16 \mathrm{~g} \mathrm{~N} \mathrm{~m}^{-2}$ observed in three cuts of field-grown mixed orchard grass (Dactylis glomerata L.)-red clover by Farnham and George (1993), and the 15-25 $\mathrm{g} \mathrm{N} \mathrm{m}^{-2}$ found in mixed perennial ryegrass-red clover by Dahlin and Stenberg (2010a). The positive correlation between $\mathrm{N}_{2}$ fixation and soil EC suggests that nutrient limitation may have played a role in determining the amount of $\mathrm{N}$ fixed although no single nutrient was identified by the regressions. The data further suggest that this limitation was at least partially ameliorated by application of the ash. In contrast, the amount of fixed $\mathrm{N}$ was not significantly correlated with soil $\mathrm{pH}$ on the experimental soil. Low soil pH has frequently been found to limit $\mathrm{N}_{2}$ fixation (e.g. Giller 2001) but the $\mathrm{pH}$ range in the current experiment may have been too narrow to demonstrate such an effect.

The higher ryegrass biomass on the amended soils than on the control soil at the first cut and the higher proportion and amounts of grass $\mathrm{N}$ derived from air indicate a larger supply of $\mathrm{N}$ fixed by the clover during the previous growing season. Nevertheless, the $\mathrm{N}$ derived from air recovered in the grass only contributed $1-7 \%$ of the fixed $\mathrm{N}$. This and the amount of fixed $\mathrm{N}$ transferred to the grass $\left(<0.3 \mathrm{~g} \mathrm{~N} \mathrm{~m}^{-2}\right)$ were at the lower end of the range $(1.7$ $-3.6 \mathrm{~g} \mathrm{~N} \mathrm{~m}^{-2}$ ) reported by Høgh-Jensen and Schjoerring (2000), Dahlin and Stenberg (2010b) and Pirhofer-Walzl et al. (2012). This suggests that the strong dominance of the clover in the mixtures at the second cut restricted utilisation by the grass of fixed $\mathrm{N}$ present in the soil. 
The initial increase in uptake of soil $\mathrm{N}$ by the clover on the ash-amended soil compared with the control suggests a moderate need for fixed $\mathrm{N}$, which may have contributed to the lack of effect on the percentage of $\mathrm{N}$ derived from air despite increased total $\mathrm{N}$ accumulation. This confirms earlier findings that $\mathrm{N}_{2}$ fixation is to a large degree determined by plant $\mathrm{N}$ demand (Ledgard and Steele 1992). The increased soil $\mathrm{N}$ uptake by the ash-amended clover in the first cut could possibly be due to a temporary increase in $\mathrm{N}$ mineralisation, as there was a tendency for higher total soil $\mathrm{N}$ use in this cut. However, the difference was non-significant and the total uptake of soil-derived $\mathrm{N}$ by the crop mixtures across the two cuts was similar in all treatments. Furthermore, a potential short-term increase in $\mathrm{N}$ mineralisation upon ash application would most likely have subsided during the harvest year, as the ash had been applied the previous year. Hence, more rapid clover establishment and root development are plausible factors behind the higher use of soil $\mathrm{N}$. Release of 'native' soil N through increased mineralisation-immobilisation turnover after higher $\mathrm{N}_{2}$ fixation in the ash-amended soil in the preceding season may have contributed, but most likely only to a limited extent. In contrast to our results, Weber et al. (1985) found that wood ash application at 10 t ha-1 increased $\mathrm{N}$ mineralisation and decreased soil $\mathrm{N}$ pools. However, at the current, lower application rate, the $\mathrm{pH}$ increase was moderate and apparently not sufficient to measurably increase $\mathrm{N}$ mineralisation. With increased biomass production and total $\mathrm{N}_{2}$ fixation, the overall effect of wood ash amendment at moderate rates may, on the contrary, be an increase in soil $\mathrm{C}$ and $\mathrm{N}$ pools under legume-rich leys.

\section{Conclusions}

Wood ash amendment of a nutrient-poor soil increased $\mathrm{N}_{2}$ fixation and clover growth and also increased the clover proportion in a mixed grass-clover crop. Thus wood ash high in nutrients (but low in pollutants) can be successfully used as a multi-element soil amendment to enhance clover growth on low-fertility soils. However, further studies, including field experiments, are required to confirm these findings, and it is vital that ash quality is confirmed through analysis to minimise application of potentially toxic elements. The effects of crushed rock amendment were small or non-significant. Combined with the monetary and environmental costs of transport, this suggests that crushed rock of this type is unlikely to become a significant means of nutrient supply to northern hemisphere soils, except perhaps at sites close to the source.

\section{Acknowledgements}

The ${ }^{15} \mathrm{~N}$ analyses and data evaluation were funded by the $\mathrm{CL}$ Behm Foundation in Sweden. The pot experiment revisited here was funded by the Swedish Research Council for Environment, Agricultural Sciences and Spatial Planning (Formas).

\section{References}

Bakken, A.K., Gautneb, H., Sveistrup, T. \& Myhr, K. 2000. Crushed rocks and mine tailings applied as K fertilizers on grassland. Nutrient Cycling in Agroecosystems 56: 53-57. https://doi.org/10.1023/A:1009709914578

Brod, E., Haraldsen, T.K. \& Breland T.A. 2012. Fertilization effects of organic waste resources and bottom wood ash: results from a pot experiment. Agricultural and Food Science 21: 332-347.

Brod, E., Haraldsen, T. K. \& Krogstad, T. 2014. Combined waste resources as compound fertiliser to spring cereals. Acta Agriculturae Scandinavica Section B-Soil and Plant Science 64: 329-340. https://doi.org/10.1080/09064710.2014.907928

Campbell, N. 2009. The use of rockdust and composted materials as soil fertility amendments. (Doctor of Philosophy), University of Glasgow, Glasgow Theses Service. 402 p. http://theses.gla.ac.uk/617/01/2009campbelllphd.pdf.

Clapham, W.M. \& Zibilske, L.M. 1992. Wood ash as a liming amendment. Communications in Soil Science and Plant Analysis 23: 1209-1227. https://doi.org/10.1080/00103629209368661

Dahlin, A.S., Edwards, A.C., Lindstrom, B.E.M., Ramezanian, A., Shand, C.A., Walker, R.L., Watson, C.A. \& Öborn, I. 2012. Revisiting herbage sample collection and preparation procedures to minimise risks of trace element contamination. European Journal of Agronomy 43: 33-39. https://doi.org/10.1016/j.eja.2012.04.007

Dahlin, A.S., Ramezanian, A., Campbell, C.D., Hillier, S. \& Öborn, I. 2015. Waste recovered by-products can increase growth of grass-clover mixtures in low fertility soils and alter botanical and mineral nutrient composition. Annals of Applied Biology 166: 105-117. https://doi.org/10.1111/aab.12168

Dahlin, A.S. \& Stenberg, M. 2010a. Cutting regime affects the amount and allocation of symbiotically fixed $\mathrm{N}$ in green manure leys. Plant and Soil 331: 401-412. https://doi.org/10.1007/s11104-009-0261-1

Dahlin, A.S. \& Stenberg, M. 2010b. Transfer of N from red clover to perennial ryegrass in mixed stands under different cutting strategies. European Journal of Agronomy 33: 149-156. https://doi.org/10.1016/j.eja.2010.04.006

Demeyer, A., Nkana, J.C.V. \& Verloo, M.G. 2001. Characteristics of wood ash and influence on soil properties and nutrient uptake: an overview. Bioresource Technology 77: 287-295. https://doi.org/10.1016/S0960-8524(00)00043-2 
Farnham, D.E. \& George, J.R. 1993. Dinitrogen fixation and nitrogen transfer among red clover cultivars. Canadian Journal of Plant Science 73: 1047-1054. https://doi.org/10.4141/cjps93-136

Ferreiro, A., Merino, A., Diaz, N. \& Pineiro, J. 2011. Improving the effectiveness of wood-ash fertilization in mixed mountain pastures. Grass and Forage Science 66: 337-350. https://doi.org/10.1111/j.1365-2494.2011.00800.x

Giller KE. 2001. Nitrogen fixation in tropical cropping systems. 2nd ed. ISBN 0851994172 . CABI Publishing, Wallingford, UK. 423 p. https://doi.org/10.1079/9780851994178.0000

Hansen, J.P. \& Vinther, F.P. 2001. Spatial variability of symbiotic $\mathrm{N}_{2}$ fixation in grass-white clover pastures estimated by the $15 \mathrm{~N}$ isotope dilution method and the natural 15N abundance method. Plant and Soil 230: 257-266. https://doi.org/10.1023/A:1010390901845

Haraldsen, T.K., Pedersen, P.A. \& Grønlund, A. 2011. Mixtures of Bottom Wood Ash and Meat and Bone Meal as NPK Fertilizer. In: Insam, H. \& Knapp, B.A. (eds.). Recycling of Biomass Ashes. Berlin Heidelberg, Germany: Springer-Verlag. p. 33-44. https:// doi.org/10.1007/978-3-642-19354-5_3

Hillier, S. 1999. Use of an air brush to spray dry samples for X-ray powder diffraction. Clay Minerals 34: 127-135. https://doi. org/10.1180/000985599545984

Høgh-Jensen, H. \& Schjoerring, J.K. 2000. Below-ground nitrogen transfer between different grassland species: Direct quantification by $15 \mathrm{~N}$ leaf feeding compared with indirect dilution of soil 15N. Plant and Soil 227: 171-183. https://doi. org/10.1023/A:1026535401773

Holm, S. 1979. A simple sequentially rejective multiple test procedure. Scandinavian Journal of Statistics 6: 65-70.

ISO 1998. Soil quality - Determination of particle size distribution in mineral soil material - Method by sieving and sedimentation. ISO 11277:1998. https://www.iso.org/standard/54151.html

Jarrell, W.M. \& Beverly, R.B. 1982. The dilution effect in plant nutrition studies. Advances in Agronomy 34: 197-224. https://doi. org/10.1016/S0065-2113(08)60887-1

Kahnt, G., Pfleiderer, H. \& Hijazi, L.A. 1986. Effect of amelioration doses of rock powder and rock sand on growth of agricultural plants and on physical characteristics of sandy and clay soils. Journal of Agronomy and Crop Science-Zeitschrift Fur Acker Und Pflanzenbau 157: 169-180. https://doi.org/10.1111/j.1439-037X.1986.tb00064.x

Ledgard, S.F. \& Steele, K.W. 1992. Biological nitrogen-fixation in mixed legume grass pastures. Plant and Soil 141: 137-153. https://doi.org/10.1007/BF00011314

Manning, D.A.C. 2010. Mineral sources of potassium for plant nutrition. A review. Agronomy for Sustainable Development 30: 281-294. https://doi.org/10.1051/agro/2009023

Omotoso, O., McCarty, D.K., Hillier, S. \& Kleeberg, R. 2006. Some successful approaches to quantitative mineral analysis as revealed by the 3rd Reynolds Cup contest. Clays and Clay Minerals 54: 748-760. https://doi.org/10.1346/CCMN.2006.0540609

Parker, F.W. 1929. The origin, nature, and isolation of the inorganic base exchange compound of soil. Journal of the American Society of Agronomy 21: 1030-1039. https://doi.org/10.2134/agronj1929.00021962002100110003x

Pilbeam, D.J., \& Morley, P.S. 2007. Calcium. In: Barker, A.V. \& Pilbeam, D.J. (eds.). Handbook of Plant Nutrition. New York, USA: CRC Press. p. 121-144.

Pirhofer-Walzl, K., Rasmussen, J., Høgh-Jensen, H., Eriksen, J., Søegaard, K. \& Rasmussen, J. 2012. Nitrogen transfer from forage legumes to nine neighbouring plants in a multi-species grassland. Plant and Soil 350: 71-84. https://doi.org/10.1007/s11104011-0882-z

Ramezanian, A., Dahlin, A.S., Campbell, C.D., Hillier, S., Mannerstedt-Fogelfors, B. \& Öborn, I. 2013. Addition of a volcanic rockdust to soils has no observable effects on plant yield and nutrient status or on soil microbial activity. Plant and Soil 367: 419-436. https://doi.org/10.1007/s11104-012-1474-2

Shearer, G. \& Kohl, D.H. 1986. N-2-fixation in field settings - estimations based on natural N-15 abundance. Australian Journal of Plant Physiology 13: 699-756.

Snoeck, D., Zapata, F. \& Domenach, A.-M. 2000. Isotopic evidence of the transfer of nitrogen fixed by legumes to coffee trees. Biotechnology, Agronomy, Society and Environment 4: 95-100.

SSI 1993. Soil analysis. Extraction and determination of phosphorus, potassium, calcium, magnesium and sodium from soils with ammonium lactate/acetic acid solution. Volume SS 028310. Stockholm, Sweden: Swedish Standards Institute. 7 p. (in Swedish).

Streck, T. \& Richter, J. 1997. Heavy metal displacement in a sandy soil at the field scale .1. Measurements and parameterization of sorption. Journal of Environmental Quality 26: 49-56. https://doi.org/10.2134/jeq1997.00472425002600010008x

Sumner, M.E. 1994. Measurement of soil-pH - problems and solutions. Communications in Soil Science and Plant Analysis 25 : 859-879. https://doi.org/10.1080/00103629409369085

Swedish Environmental Protection Agency 1994. Naturvårdsverkets författningssamling. SNFS 1994:2 MS:72. http://www.naturvardsverket.se/Documents/foreskrifter/nfs1994/snfs1994-02k.pdf. (Accessed 14 March 2017).

Thomas, G.W. 1982. Chemical and microbiological properties. In: A.L. Page, R.H. Miller and D.R. Keeney. (eds.). Methods of Soil Analysis Part 2. 2nd edn. Madison, WI, USA: SSSA. p. 159-165.

Weber, A., Karsisto, M., Leppänen, R., Sundman, V. \& Skujins, J. 1985. Microbial activities in a Histosol: effects of wood ash and NPK fertilizers. Soil Biology \& Biochemistry 17: 291-296. https://doi.org/10.1016/0038-0717(85)90063-X

Whitehead, D.C. 2000. Nutrient Elements in Grassland: Soil-Plant-Animal Relationships. Wallingford, UK, Cab International. 369 p. https://doi.org/10.1079/9780851994376.0000

Zake, J.Y.K. \& Nkwiine, C. 1982. The effect of ash, calcium carbonate and inoculation on nitrogen fixation and yield of beans (Phaseolus vulgaris) variety K20. In: J.N. Qureshi, F.N. Muchena, C.M. Njihia, N. Njeru \& S.M. Mugambi (eds.). Proceedings of the 5th annual general meeting of the Soil Science Society of East Africa. p. 46-55. 